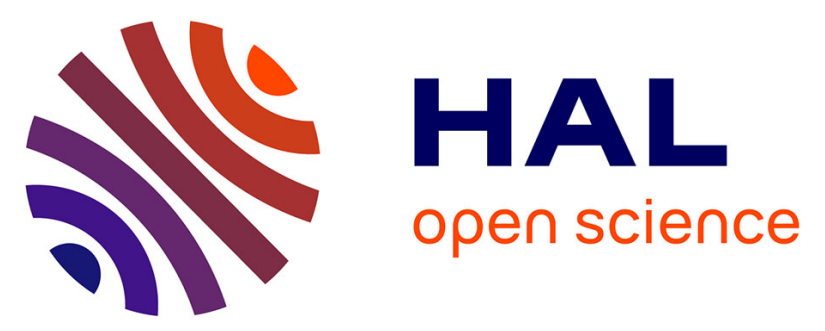

\title{
The Natural Mutation Encoding a C Terminus-Truncated 5-Hydroxytryptamine2B Receptor Is a Gain of Proliferative Functions
}

\author{
Maud Deraet, Philippe Manivet, Agnes Janoshazi, Jacques Callebert, Silke \\ Guenther, Ludovic Drouet, Jean-Marie Launay, Luc Maroteaux
}

\section{To cite this version:}

Maud Deraet, Philippe Manivet, Agnes Janoshazi, Jacques Callebert, Silke Guenther, et al.. The Natural Mutation Encoding a C Terminus-Truncated 5-Hydroxytryptamine2B Receptor Is a Gain of Proliferative Functions. Molecular Pharmacology, 2005, 67 (4), pp.983 - 991. 10.1124/mol.104.008268 . hal-01596608

\section{HAL Id: hal-01596608 \\ https://hal.science/hal-01596608}

Submitted on 27 Sep 2017

HAL is a multi-disciplinary open access archive for the deposit and dissemination of scientific research documents, whether they are published or not. The documents may come from teaching and research institutions in France or abroad, or from public or private research centers.
L'archive ouverte pluridisciplinaire HAL, est destinée au dépôt et à la diffusion de documents scientifiques de niveau recherche, publiés ou non, émanant des établissements d'enseignement et de recherche français ou étrangers, des laboratoires publics ou privés. 
Title Page.

The natural mutation encoding a C-terminus truncated $5-\mathrm{HT}_{2 \mathrm{~B}}$ receptor is a gain of proliferative functions

Maud Deraet, Philippe Manivet, Agnes Janoshazi, Jacques Callebert, Silke Guenther, Ludovic Drouet, Jean-Marie Launay, Luc Maroteaux

MD, AJ, SG, LM, Institut de Génétique et de Biologie Moléculaire et Cellulaire, CNRS, INSERM, Université L. Pasteur de Strasbourg, BP 1014267404 ILLKIRCH CEDEX - France;

PM, JC, LD, JML, IFR6, Services de Biochimie et d'Angio-Hématologie, Hôpital Lariboisière, 2 rue Ambroise Paré, 75475 PARIS CEDEX 10-France

LM, Present address:INSERM U616 Hospital Pitié-Salpetrière Bat Pédiatrie 47 bd de l'Hôpital 75651

PARIS CEDEX 13 France 
Running Title Page.

Running title. Gain of function in a natural $5-\mathrm{HT}_{2 \mathrm{~B}}$ receptor mutant

Correspondence to L.M.: luc.maroteaux@ chups.jussieu.fr, Tel: 33 1.42.16.26.73 Fax: 33 1.45.70 99.90

Number of text pages,

Number of supplementary data

Number of figures,

Number of tables,

Number of references,

Number of words in the abstract,

Number of words in the Introduction, 744

Number of words in the Discussion. $\quad 1172$
3

3

1

31

230

\section{List of non-standard abbreviations}

(6)-[ $\left.{ }^{125} \mathrm{I}\right] 1$-(2,5-dimethoxy-4-iodophenyl)- 2-aminopropane $\mathrm{HCl}\left(\left[{ }^{125} \mathrm{I}\right] \mathrm{DOI}\right.$; G-protein coupled receptor (GPCR); G-protein coupled receptor kinase (GRK); human herpes virus 8 (HHV8); mitogen-activated protein kinase (MAPK); Multi-PDZ domain containing protein 1 (MUPP1); nuclear factor kappa B (NFkappa B); nitric oxide synthase (NOS); PSD-95, Dlg, ZO-1 (PDZ); serum response element (SRE) 


\begin{abstract}
.
Although potentially implicated in several physiological functions, few functional mutations have been identified in the human 5- $\mathrm{HT}_{2 \mathrm{~B}}$ receptor gene. Recently, a heterozygous mutation $\mathrm{R} 393 \mathrm{X}$ in the 5- $\mathrm{HT}_{2 \mathrm{~B}}$ receptor was identified in one patient diagnosed with pulmonary hypertension after intake of the anorexigen dexfenfluramine. Although reported to generate a lack of function, this C-terminus truncated 5-HT $2 \mathrm{~B}$ receptor should somehow affect transduction pathways relevant to pulmonary hypertension. In our study, we investigated putative modifications in transduction of the R393X mutated 5-HT $2 \mathrm{~B}$ receptor. In stably transfected cells, we confirmed the loss of $\mathrm{IP}_{3}$ stimulation due to the $\mathrm{G}_{\alpha q}$ uncoupling, despite conserved ligand affinity between the normal and mutated receptors. We also observed a partial loss of nitric oxide synthase stimulation. However, the truncated R393X receptor presented (i) a strong gain of efficacy in cell proliferation as assessed by mitogen-activated protein kinase activity and thymidine incorporation, (ii) a preferential coupling to $\mathrm{G}_{\alpha 13}$ as shown by blocking antiserum, and (iii) an apparent lack of internalization upon agonist stimulation as observed by confocal microscopy. This work demonstrates that, in the 5- $\mathrm{HT}_{2 \mathrm{~B}}$ receptor, the C-terminus including the palmitoylation and phosphorylation sites is absolutely required for proper transduction and internalization. For the first time, we show that the lack of $\mathrm{C}$-terminus can generate a switch of coupling to $\mathrm{G}_{\alpha 13}$, a reduced NO synthase activation and an increase in cell proliferation. All these modifications are relevant in pathophysiological vasoconstriction.
\end{abstract}




\section{Introduction.}

Knowledge of 5- $\mathrm{HT}_{2 \mathrm{~B}}$ receptors genetic variants is of the utmost interest in view of the involvement of these receptors in various pathologies (Roth and Shapiro, 2001). Few studies have investigated mutations in the 5- $\mathrm{HT}_{2 \mathrm{~B}}$ receptor gene (MIM 601122). It was identified as a candidate gene in obsessive-compulsive disorder: one single nucleotide polymorphism was described in intron 1 but no evidence for functional mutation was found in the coding regions of 5-HT $2 \mathrm{~B}$ receptor (Kim et al., 2000). More recently, by investigating the 5- $\mathrm{HT}_{2 \mathrm{~B}}$ receptor gene in patients who developed pulmonary hypertension after intake of fenfluramines, a heterozygous mutation was found in one female who five years before, followed a nine months anorexigen treatment (Blanpain et al., 2003). The reported mutation consists of a C/T transition resulting in the substitution of a stop codon instead of arginine 393 of the predicted protein sequence (R393X). This mutation truncates the complete carboxy-terminal tail of the receptor, removing (i) putative palmitoylation and phosphorylation sites essential for the internalization process (Parker et al., 2003) and (ii) the PSD-95, Dlg, ZO-1 (PDZ) binding motif involved in the coupling of nitric oxide synthase (NOS) (Manivet et al., 2000) or other scaffold proteins (Becamel et al., 2004).

The 5- $\mathrm{HT}_{2 \mathrm{~B}}$ receptor transduction pathways may greatly depend on cell types, but cell transfection appears to be an indispensable tool to solve the complexity of 5- $\mathrm{HT}_{2 \mathrm{~B}}$ receptor-coupling mechanisms. Blanpain's group described by transient transfection that in spite of normal expression at the plasma membrane and normal agonist binding, this $\mathrm{R} 393 \mathrm{X}$ mutation causes loss of $5-\mathrm{HT}_{2 \mathrm{~B}}$ receptor function as measured by $\mathrm{IP}_{3}$ production and calcium-dependent aequorin luminescence (Blanpain et al., 2003). In this study, the mutated receptor displayed no constitutive activity compared with the wildtype receptor, and did not produce dominant negative effects over the $\mathrm{IP}_{3} / \mathrm{Ca}^{2+}$ pathway in cotransfection experiments.

Noteworthy, coupling of 5- $\mathrm{HT}_{2 \mathrm{~B}}$ receptors to $\mathrm{IP}_{3}$ stimulation has never been observed in vivo despite its contractile effects in rat stomach (Cox and Cohen, 1995) or vasculature (Ellis et al., 1995), or its proliferative effect in carcinoid tumor cells (Launay et al., 1996). Moreover, 5- $\mathrm{HT}_{2 \mathrm{~B}}$ receptor can trigger $\mathrm{IP}_{3}$ independent $-\mathrm{Ca}^{2+}$ release from ryanodine-sensitive intracellular stocks in lung endothelial cells (Ullmer et al., 1996). Most of mutations in G-protein coupled receptor (GPCR) leading to loss of 
function are autosomal recessive whereas most disease caused by GPCR as gain of function mutations are inherited in an autosomal dominant manner (Spiegel and Weinstein, 2004). If the heterozygous R393X 5$\mathrm{HT}_{2 \mathrm{~B}}$ receptor mutation is related to the pulmonary hypertension, it must trigger transduction alterations relevant to this pathology.

Previous studies established that, in addition to its role in phosphoinositide hydrolysis, the 5-HT $2 \mathrm{~B}$ receptor can transactivate growth factor receptors that control mitogen-activated protein kinase (MAPK) signaling and cell cycle progression (Launay et al., 1996; Nebigil et al., 2000). The 5-HT $2 \mathrm{~B}$ receptor protein is overexpressed in lung arteries of pulmonary hypertension patients as well as in mice chronically submitted to hypoxia, a model that shares several features with pulmonary hypertension (Launay et al., 2002). The 5- $\mathrm{HT}_{2 \mathrm{~B}}$ receptor is required for smooth muscle cell proliferation and structural remodeling of arteries, consistent with the ability of 5- $\mathrm{HT}_{2 \mathrm{~B}}$ receptor to initiate cell cycle progression in mouse fibroblasts (Nebigil et al., 2000). The 5- $\mathrm{HT}_{2 \mathrm{~B}}$ receptor can also elicit a reversible endotheliumdependent relaxation of pulmonary arteries, associated with an increase in cyclic GMP (Glusa and Pertz, 2000), through coupling to endothelial NOS. The 5- $\mathrm{HT}_{2 \mathrm{~B}}$ receptor dependent NOS activation requires the PDZ motif at the C-terminus (Manivet et al., 2000). As the R393X mutation abolishes $\mathrm{IP}_{3}$ release and removes the C-terminus PDZ motif, Blanpain et al. (Blanpain et al., 2003) suggested that the mutated receptor had lost its $\mathrm{G}_{\mathrm{q}}$ coupling, and probably its ability to stimulate NOS. Besides endotheliumdependent vasodilatation, the 5- $\mathrm{HT}_{2 \mathrm{~B}}$ receptor could participate in pulmonary arterial smooth muscle cells proliferation or remodeling (Launay et al., 2002). If this 5- $\mathrm{HT}_{2 \mathrm{~B}}$ receptor myoproliferative effect is relevant to smooth muscle cells in pulmonary hypertension patients, we hypothesize that it should be affected by the mutated R393X allele. In this study, we therefore investigated a putative gain of function of the R393X 5- $\mathrm{HT}_{2 \mathrm{~B}}$ receptor and showed that despite its loss of $\mathrm{IP}_{3}$ stimulation due to $\mathrm{G}_{\alpha \mathrm{q}}$ uncoupling and its loss of endothelial NOS stimulation due to the absence of the PDZ binding domain, this receptor retains some NO coupling, and presents higher efficacy for cell proliferation via a nearly exclusive $\mathrm{G}_{\alpha 13}$ coupling. In addition to the switch in coupling pathways, $\mathrm{R} 393 \mathrm{X}$ 5- $\mathrm{HT}_{2 \mathrm{~B}}$ receptor showed no apparent internalization upon agonist stimulation. 


\section{Materials and Methods.}

Reagents - Neurochemicals were kindly provided by Roche, Lilly and SmithKlineBeecham companies (See table for chemical makeup of compounds number). All other chemicals were reagent grade, purchased from commercial sources. The radioactive compound (6)-[ $\left.{ }^{125} \mathrm{I}\right] 1$-(2,5-dimethoxy-4iodophenyl)- 2-aminopropane $\mathrm{HCl}$ ([ $\left.\left.{ }^{125} \mathrm{I}\right] \mathrm{DOI}, 81.4 \mathrm{TBq} / \mathrm{mmol}\right)$ was purchased from DuPont NEN. Rabbit antisera against rodent $\mathrm{G}_{\mathrm{s}}(\mathrm{C}-18), \mathrm{G}_{\mathrm{q} / 11}(\mathrm{C}-19)$ and $\mathrm{G}_{13}(\mathrm{~A}-20)$ are from Santa Cruz Biotechnology (Santa Cruz, CA).

Mutagenesis - The different constructs of the human wildtype 5- $\mathrm{HT}_{2 \mathrm{~B}}$ and truncated 5- $\mathrm{HT}_{2 \mathrm{~B}}$ receptor cDNA were performed by PCR. The mutated reading frames were subcloned into enhanced GFP variants, pEYFP fused at the N-terminus to generate wildtype 5-HT $2 \mathrm{~B}$ receptor-pEYFP and $\mathrm{R} 393 \mathrm{X}$ 5-HT $2 \mathrm{~B}$ receptor-pEYFP. All the constructs were verified by sequencing before transfection.

Cell culture - LMTK$^{-}$cell lines were maintained in Dulbecco's modified Eagle's medium (Gibco) supplemented with $10 \%$ fetal bovine serum. For transfection experiments, cells were seeded at a density of $1.5 \times 10^{6}$ cells $/ 10 \mathrm{~mm}$ dish and cultured for $24 \mathrm{~h}$. Transient transfection was then performed using Jet Pei according the manufacturer's recommendations. The cells were then cultured in the same medium for 48h. The stable expressing human 5- $\mathrm{HT}_{2 \mathrm{~B}}$ receptor and $\mathrm{R} 393 \mathrm{X}$ 5- $\mathrm{HT}_{2 \mathrm{~B}}$ receptor were grown with 0.8 $\mathrm{mg} / \mathrm{ml} \mathrm{G} 418$.

Confocal Imaging - LMTK $^{-}$cells expressing wildtype 5- $\mathrm{HT}_{2 \mathrm{~B}}$ receptor-pEYFP or R393X 5- $\mathrm{HT}_{2 \mathrm{~B}}$ receptor-pEYFP were grown in a glass bottom dish and observed in serum free medium at room temperature. To visualize the receptor internalization movement after agonist treatment, time-lapse series were taken every $5 \mathrm{~min}$ over a $30 \mathrm{~min}$ period. To calculate the internalization kinetics of the receptors, we selected more than 5 regions of interest on the membrane per cell and followed the relative intensity changes of these regions over time, following 3 individual cells per experiment. Our data represent more than four independent experiments. The kinetic curves were corrected for the bleaching by using the intensity of the whole cell as a normalization factor. 
Radioligand Binding Experiments — Radioligand binding experiments were performed as previously detailed (Tournois et al., 1998). Stable LMTK ${ }^{-}$clones expressed 178, and 128 fmol of 5-HT 2 B receptor and $\mathrm{R} 393 \mathrm{X} 5-\mathrm{HT}_{2 \mathrm{~B}}$ receptor /mg of protein, respectively, as measured by [ $\left.{ }^{125} \mathrm{I}\right] \mathrm{DOI}$ binding.

Determination of Intracellular Inositol 1,4,5-Trisphosphate Levels - Cells were washed twice with fresh serum-free medium, incubated for 5 min at $37{ }^{\circ} \mathrm{C}$ with agonists and scraped with a rubber policeman. Intracellular $\mathrm{IP}_{3}$ levels were then measured by radioreceptor assay as previously detailed (Tournois et al., 1998). The Emax for serotonin of the wildtype receptor was 120 pmoles/mg of proteins. NOS Assay - Cells were incubated with agonists for $10 \mathrm{~min}$. Cell lysate supernatant proteins were assayed for NOS activity by monitoring the conversion of $\left[{ }^{3} \mathrm{H}\right]$-labeled L-arginine to $\left[{ }^{3} \mathrm{H}\right]$ labeled Lcitrulline as described previously (Manivet et al., 2000). The Emax for serotonin of the wildtype receptor was $16 \mathrm{pmoles} / \mathrm{mg} \mathrm{prot} / \mathrm{min}$.

Assay of MAP Kinase Activity — Cells were incubated with agonists for 20 min. Cell lysate supernatant proteins were assayed for kinase activity in reaction buffer containing $1 \mu \mathrm{Ci}$ of $\left[\gamma^{32} \mathrm{P}\right] \mathrm{ATP}, 20 \mu \mathrm{M}$ ATP, and $1.5 \mathrm{mg} / \mathrm{ml}$ myelin basic protein (MBP) (Sigma) for $20 \mathrm{~min}$ at $30{ }^{\circ} \mathrm{C}$, essentially as described (Launay et al., 1996). The Emax for serotonin of the wildtype receptor was 1.15 pmoles $/ \mathrm{mg}$ prot $/ 10 \mathrm{~min}$. Thymidine Incorporation - Cells were seeded on 24-well plates at a density of $10^{3}$ cells per well, grown overnight, and serum-starved for $24 \mathrm{~h}$. Quiescent cells were treated with serotonin at different concentrations for $18 \mathrm{~h}$, and $0.5 \mu \mathrm{Ci}(1 \mathrm{Ci}=37 \mathrm{GBq})$ of $\left[{ }^{3} \mathrm{H}\right]$ thymidine was added to the culture during the last $4 \mathrm{~h}$ of incubation. The free radioactive thymidine was washed away in $5 \%$ trichloroacetic acid, and the incorporated radioactive thymidine was quantified by scintillation counting as described (Nebigil et al., 2000).

Cell Permeabilization - The cells were washed twice with phosphate buffered saline containing $0.1 \%$ bovine serum albumin and exposed to 1 hemolytic unit of alveolysin $/ 10^{6}$ cells at $37^{\circ} \mathrm{C}$ under agitation as described (Manivet et al., 2000).

Statistics - Binding data were analyzed using the iterative non-linear fitting software Graphpad-Prism 2.0. This allowed to calculate inhibition constants $\left(K_{i}\right)$ according to the Cheng-Prusoff equation. All 
values represent average of independent experiments \pm SEM ( $n=$ number of experiments as indicated in the text). Comparisons between groups were performed using Student unpaired t test or ANOVA and a Fischer test. Significance was set at $\mathrm{p}<0.05$. 


\section{Results.}

Since it was not possible to study the mutated 5- $\mathrm{HT}_{2 \mathrm{~B}}$ receptors $\mathrm{R} 393 \mathrm{X}$ in patient's native tissues, we used stable recombinant expression systems. The two human 5- $\mathrm{HT}_{2 \mathrm{~B}}$ receptors cDNA, wildtype and R393X, were stably transfected into $\mathrm{LMTK}^{-}$cells thus ensuring they were studied in an identical cell background. Under the same experimental paradigm, parental non-transfected cells did not exhibit a concentration dependent rise in second messengers after agonist stimulation. Single clones were chosen for each receptor according their relatively low expression in order to be as close as possible to physiological levels. Moreover, cells were used at nearly similar passages to ensure stable expression levels. Classical pharmacological binding studies clearly confirmed that the R393X mutation had no significant effect on the binding profile of either agonists or antagonists (table). We also confirmed that the $\mathrm{IP}_{3}$ coupling was lost by this mutated receptor (table). However, since NO coupling and cell proliferation may be more physiologically relevant signaling pathways for this receptor, we asked if the R393X mutation had differential effect on these two pathways.

Pharmacological values obtained for R393X 5- $\mathrm{HT}_{2 \mathrm{~B}}$ receptor vs. wildtype receptor clearly demonstrates that EC50s for NO coupling were increased for all agonists (Figure 1, table, and supplementary figure). For some ligands like serotonin the EC50 was increased by a factor 10. The maximal levels of NOS activation (Emax) were all reduced. The Emax for serotonin was reduced by $40 \%$, serotonin behaving as a partial agonist. The Emax for DOI changed from more than $40 \%$ of that of serotonin for wildtype receptor to $14 \%$ for the mutant receptor, DOI becoming a nearly silent agonist (Table). Most $\mathrm{K}_{B} \mathrm{~s}$ for antagonists were increased (Table and supplementary figure). These results indicate a partial loss of NO coupling by the R393X receptor.

At the opposite, most EC50s for the coupling to MAPK activation were decreased. BW723C86 (a selective 5-HT $2 \mathrm{~B}$ receptor agonist) showed a 7 fold decreased EC50. Interestingly, the Emax of R393X 5$\mathrm{HT}_{2 \mathrm{~B}}$ receptor for serotonin was increased by $27 \%$ over the wildtype value and the Emax for norDF changed from $73 \%$ to $86 \%$ of that of serotonin for the wildtype receptor (Figure 1 and table). For antagonists, most $\mathrm{K}_{B} \mathrm{~S}$ toward MAPK activation were increased, by 20 fold for ritanserin for example 
(Figure 1 and supplementary figure). These results indicate a clear gain of efficacy in MAPK stimulation by the $\mathrm{R} 393 \mathrm{X}$ receptor.

Since previous studies have indicated that $5-\mathrm{HT}_{2 \mathrm{~B}}$ receptor-dependent MAPK activation can led to cell proliferation and/or survival, we performed a proliferation assay on both cell lines expressing either wildtype or R393X 5- $\mathrm{HT}_{2 \mathrm{~B}}$ receptors. According to these studies, agonist activation of 5- $\mathrm{HT}_{2 \mathrm{~B}}$ receptors triggered cell proliferation as assessed by tritiated thymidine incorporation. In agreement to the pharmacological study on MAPK activation, the cell proliferation triggered by stimulation of the R393X mutated 5- $\mathrm{HT}_{2 \mathrm{~B}}$ receptor was strikingly increased ( 3 fold at $1 \mu \mathrm{M}$ serotonin) and the stimulation by 100 $\mathrm{nM}$ serotonin of this mutated receptor was similar to that of the wildtype receptor by $1 \mu \mathrm{M}$ serotonin (Figure 3A). Basal thymidine incorporation was also elevated in $\mathrm{R} 393 \mathrm{X} 5-\mathrm{HT}_{2 \mathrm{~B}}$ receptor $(1.7 \pm 0.3$ fold basal wildtype, $n=8$ ). These results indicate a clear gain of efficacy in thymidine incorporation and thus of cell proliferation for $\mathrm{R} 393$ X 5-HT $2 \mathrm{~B}$ receptor.

We further investigated this gain of cell proliferation using blocking antibodies to various Gproteins on alveolysin permeabilized living cells. We observed that the thymidine incorporation was controlled by both $\mathrm{G}_{\mathrm{q}}$ and $\mathrm{G}_{13}$ in the wildtype receptor expressing cells. Indeed, anti $\mathrm{G}_{\mathrm{s}}$ antiserum was inactive in the same assay. By contrast, the thymidine incorporation appeared nearly entirely dependent on $\mathrm{G}_{13}$, but not anymore on $\mathrm{G}_{\mathrm{q}}$ (nor $\mathrm{G}_{\mathrm{s}}$ ) in $\mathrm{R} 393 \mathrm{X}$ 5-HT $\mathrm{H}_{2 \mathrm{~B}}$ receptor expressing cells (Figure 3B). These results suggest that the gain of efficacy to cell proliferation by the $\mathrm{R} 393 \mathrm{X} 5-\mathrm{HT}_{2 \mathrm{~B}}$ receptor is subsequent to a change in G-protein coupling to $\mathrm{G}_{13}$.

Finally, previous report indicated that upon agonist stimulation, 5- $\mathrm{HT}_{2 \mathrm{~B}}$ receptor is quickly desensitized (Porter et al., 2001) phenomenon that likely rely, at least in part, on phosphorylation of residues in the C-terminus of GPCRs. We, therefore, compared the wildtype and the R393X 5-HT $2 \mathrm{~B}$ receptor-pEYFP for internalization upon stimulation by $1 \mu \mathrm{M}$ serotonin by confocal time-lapse video microscopy. Stimulation of the 5- $\mathrm{HT}_{2 \mathrm{~B}}$ receptor wildtype expressing cells led to a rapid internalization indicated by the quick disappearance of receptors from the plasma membrane with a half-life of $4.7 \pm 0.9$ $\min (\mathrm{n}=7)$. For R393X 5-HT $2 \mathrm{~B}$ receptor expressing cells, no significant internalization was detected with 
half-life longer than 60 min (Figure 4- Supplementary movies). These results indicate that the absence the C-terminus truncated receptor is either partially retained intracellularly or constitutively internalized. 


\section{Discussion.}

Using stably transfected cell lines expressing human cDNAs encoding wildtype and R393X 5-HT $2 \mathrm{~B}$ receptors, we first confirmed the initial Blanpain et al.'s results that the R393X 5- $\mathrm{HT}_{2 \mathrm{~B}}$ receptor has kept the same binding affinity for all tested compounds but lost its coupling to $G_{q}$ and to $\mathrm{IP}_{3}$. We then validated their hypothesis that endothelial NOS coupling is lost in the R393X 5-HT $2 \mathrm{~B}$ receptor. Both of these findings are loss of function.

Moreover, we demonstrate here, for the first time, that the lack of C-terminal tail containing the palmitoylation site in the $\mathrm{R} 393 \mathrm{X} 5-\mathrm{HT}_{2 \mathrm{~B}}$ receptor is associated with a loss of rapid internalization as shown by confocal analysis of YFP-tagged receptors. In addition, the R393X 5-HT $2 \mathrm{~B}$ receptor retains its capacity to stimulate NOS activity despite lower efficacy. Furthermore, the R393X 5-HT $2 \mathrm{~B}$ receptor has acquired a striking increase in proliferative capacity, as indicated by two independent criteria, an increase in MAPK Emax and in thymidine incorporation levels. These later data appear to be the consequence of a switch from a dual $G_{\alpha q} / G_{\alpha 13}$ coupling in wildtype receptor to a nearly exclusive coupling to $G_{\alpha 13}$ in the R393X 5-HT $2 \mathrm{~B}$ receptor as shown by blocking antibodies. This switch to $\mathrm{G}_{\alpha 13}$ coupling and cell proliferation are clear gain of functions for this mutant receptor in transduction pathways, which are relevant for vascular proliferation and remodeling.

In mouse LMTK ${ }^{-}$fibroblasts stably transfected with the full-length cDNA encoding the 5- $\mathrm{HT}_{2 \mathrm{~B}}$ receptor, a serotonin-dependent NO coupling mediated by endothelial and inducible NOS has been observed. The endothelial NOS stimulation is PDZ-dependent, while the inducible NOS is controlled by $\mathrm{G}_{13}$ (Manivet et al., 2000). In transfected cells expressing a partial C-terminus truncated form of the 5$\mathrm{HT}_{2 \mathrm{~B}}$ receptor (K403X), DOI-dependent $\mathrm{IP}_{3}$ coupling was retained (Manivet et al., 2000). Combined with our data, this clearly indicates that the Cysteine397 is required for the formation of the VIII $\alpha$ helix and identifies this helix as responsible for the $G_{q}$ association, since it is destroyed by the absence of the palmitoylation site, but retained in the $\mathrm{K} 403 \mathrm{X} 5-\mathrm{HT}_{2 \mathrm{~B}}$ receptor, as previously documented by structural studies of the rhodopsin/transducin interactions (Sakmar et al., 2002). 
A nearly complete lack of apparent internalization was observed in $\mathrm{R} 393 \mathrm{X} 5-\mathrm{HT}_{2 \mathrm{~B}}$ receptor by time-lapse video confocal microscopy and thus of desensitization that is especially relevant to chronic diseases. This result indicates that the truncated receptor is either partially retained intracellularly or constitutively internalized. Multi-PDZ domain containing protein 1 (MUPP1), a putative scaffolding protein with $13 \mathrm{PDZ}$ domains, was identified as a 5- $\mathrm{HT}_{2 \mathrm{C}} \mathrm{R}$-interacting protein (Ullmer et al., 1998). 5$\mathrm{HT}_{2 \mathrm{C}} \mathrm{R}$ interaction with MUPP1 is dynamically regulated by phosphorylation at Ser458 (Parker et al., 2003). Similarly, PSD-95 was shown to modulate 5-HT ${ }_{2 \mathrm{~A}} \mathrm{R}$ 's activity, intracellular trafficking, and distribution (Xia et al., 2003) and agonist-mediated desensitization of 5- $\mathrm{HT}_{2 \mathrm{~A}} \mathrm{Rs}$ requires the presence of S421 in the C-terminal tail (Gray et al., 2003). In the R393X 5- $\mathrm{HT}_{2 \mathrm{~B}}$ receptor, the truncation of most of the carboxy-terminal tail of the receptor removes putative phosphorylation sites and thus PDZ-dependent intracellular trafficking motifs, explaining likely the absence of internalization.

Besides the phosphorylation by second-messenger-activated kinases, GPCR can be also phosphorylated by GPCR kinases (GRKs), which lead to recruitment of the arrestin proteins. Recent discoveries indicate that the $\beta$-arrestins play widespread roles as scaffolds and/or adapter molecules that organize a variety of complex signaling pathways emanating from GPCRs (Miller and Lefkowitz, 2001). G-protein- independent, $\beta$-arrestin-dependent activation of MAPK has been described (Azzi et al., 2003). It was found that inverse agonists for Gs-activated adenylate cyclase could be positive partial agonists for $\beta$-arrestin-dependent MAPK activation. These authors suggested that multiple active conformations of a receptor may activate different types of effectors such as $\mathrm{G}$ proteins and beta-arrestin (Lefkowitz and Whalen, 2004). Although binding affinities are not affected by the absence of C-terminus in R393X 5$\mathrm{HT}_{2 \mathrm{~B}}$ receptors, the efficacies of compounds are differentially affected depending on the transduction pathways. The partial agonist DOI becomes a silent agonist toward NOS activity in the mutant receptor, while the partial agonist norDF (the active metabolite of dexfenfluramine) becomes a full agonist toward MAPK activation. These results clearly reinforce the notion that active conformation of GPCRs differs between different couplings and thus agonist efficacy must be dependent on cellular G-protein plethora. 
Introduction of anti- $\mathrm{G}_{13}$ antibodies in permeabilized cells systematically blocked the $5-\mathrm{HT}_{2 \mathrm{~B}}$ receptor-mediated inducible NOS activation (Manivet et al., 2000). Our present study provides also evidence that the alpha subunit of the $\mathrm{G}_{13}$ protein plays a critical role in the mechanisms of 5-HT $\mathrm{H}_{2 \mathrm{~B}}$ receptor/NOS coupling. $\mathrm{G}_{13}$ has been reported to activate inducible NOS through a mechanism distinct from other $\mathrm{G}_{\alpha}$ chains (Kitamura et al., 1996). The Src family kinase (other effectors of $\mathrm{HT}_{2 \mathrm{~B}} \mathrm{Rs}$ ) (Nebigil et al., 2000) acts upstream of Rho activation for the $\mathrm{G}_{12 / 13}$-induced JNK activation (Nagao et al., 1999). The small G-protein RhoA and its effector Rho kinase play a major role in the sustained rise in tension induced by vasoconstrictors. Rho/Rho-kinase activation is important in the effects of both acute and chronic hypoxia on the pulmonary circulation, possibly by contributing to both vasoconstriction and vascular remodeling (Fagan et al., 2004). The gain in $\mathrm{G}_{13}$ coupling of the R393X 5-HT $2 \mathrm{~B}$ receptor appears thus relevant to pathological vasoconstriction and remodeling.

Recent work on Endothelin B receptor, another Gq coupled receptor implicated in pulmonary vasoconstriction, showed that although the three intracellular loops of this receptor are involved in coupling to $G$ proteins, residues in the first intracellular loop are specifically required for activation of $G_{13}$ (Liu and $\mathrm{Wu}, 2003$ ). Interestingly, these authors have also reported that the deletion of Endothelin B receptor C-terminus up to residue Cys405, a myristoylation site, increased response of serum response element (SRE)-mediated transcription to Endothelin1 in both wildtype and $\mathrm{G}_{\mathrm{q} / 11}$ mutated fibroblasts. Their conclusion that $\mathrm{G}_{13}$ transduces signals from GPCRs to stimulate growth-promoting pathways via the SRE appears similar to the coupling of the R393X 5-HT $2 \mathrm{~B}$ receptor to cell proliferation.

A recent report showed that lung-tissue samples from several patients with pulmonary hypertension present evidence of infection with Kaposi's sarcoma herpes virus (human herpes virus 8; HHV8) suggesting a pathogenetic role in primary pulmonary hypertension (Cool et al., 2003). The HHV8 open reading frame 74 encodes a constitutively active GPCR for chemokines that leads to cell transformation and vascular overgrowth by constitutive activation of nuclear factor kappa B (NF-kappa B) and involves activation of $\mathrm{G}_{13}$ and RhoA (Shepard et al., 2001). Mouse lung endothelial cell model in which HHV8-GPCR is stably expressed, stimulates phosphatidylinositol 3-kinase and activates NF-kappa 
B (Couty et al., 2001). Since we previously reported that 5- $\mathrm{HT}_{2 \mathrm{~B}}$ receptor via phosphatidylinositol-3 kinase/Akt can activate NF-kappaB (Nebigil et al., 2003), it is tempting to speculate that HHV8-GPCR and 5- $\mathrm{HT}_{2 \mathrm{~B}}$ receptor use common $\mathrm{G}_{13}$-dependent pathways leading to vascular remodeling.

Disruption of the association between PDZ proteins and their targets contributes to the pathogenesis of a number of human diseases, most likely due to the failure of PDZ proteins to appropriately target and modulate the actions of the associated proteins. Our results not only confirm the importance of C-terminal tail of GPCR for both desensitization and coupling, but also highlight its importance for G-protein repertoire selectivity. 


\section{Acknowledgments.}

We thank P. Hickel for excellent technical assistance, Dr. S. Brooks for English corrections and Drs. F. Mentré and F. Godmard for statistical expertise. 


\section{References}

Azzi M, Charest PG, Angers S, Rousseau G, Kohout T, Bouvier M and Pineyro G (2003) Beta-arrestinmediated activation of MAPK by inverse agonists reveals distinct active conformations for G proteincoupled receptors. Proc. Natl. Acad. Sci. USA 100:11406-11411.

Becamel C, Gavarini S, Chanrion B, Alonso G, Galeotti N, Dumuis A, Bockaert J and Marin P (2004)

The serotonin 5-HT2A and 5-HT2C receptors interact with specific sets of PDZ proteins. J. Biol. Chem. 279:20257-20266.

Blanpain C, Le Poul E, Parma J, Knoop C, Detheux M, Parmentier M, Vassart G and Abramowicz MJ (2003) Serotonin 5- $\mathrm{HT}_{2 \mathrm{~B}}$ receptor loss of function mutation in a patient with fenfluramine-associated primary pulmonary hypertension. Cardiovasc. Res. 60:518-528.

Cool CD, Rai PR, Yeager ME, Hernandez-Saavedra D, Serls AE, Bull TM, Geraci MW, Brown KK, Routes JM, Tuder RM and Voelkel NF (2003) Expression of human herpesvirus 8 in primary pulmonary hypertension. N. Engl. J. Med. 349:1113-1122.

Couty JP, Geras-Raaka E, Weksler BB and Gershengorn MC (2001) Kaposi's sarcoma-associated herpesvirus G protein-coupled receptor signals through multiple pathways in endothelial cells. J. Biol. Chem. 276:33805-33811.

Cox DA and Cohen ML (1995) 5-Hydroxytryptamine ${ }_{2 B}$ receptor signaling in rat stomach fundus: role of voltage-dependent calcium channels, intracellular calcium release and protein kinase C. J. Pharmacol. Exp. Ther. 172:143-150.

Ellis ES, Byrne C, Murphy OE, Tilford NS and Baxter GS (1995) Mediation by 5-hydroxytryptamine $2 \mathrm{~B}$ receptors of endothelium-dependent relaxation in rat jugular vein. Br. J. Pharmacol. 114: 400-404.

Fagan KA, Oka M, Bauer NR, Gebb SA, Ivy DD, Morris KG and McMurtry IF (2004) Attenuation of acute hypoxic pulmonary vasoconstriction and hypoxic pulmonary hypertension in mice by inhibition of Rho-kinase. Am. J. Physiol. 287:L656-664.

Glusa E and Pertz HH (2000) Further evidence that 5-HT-induced relaxation of pig pulmonary artery is mediated by endothelial 5- $\mathrm{HT}_{2 \mathrm{~B}}$ receptors. Br. J. Pharmacol. 130:692-698. 
Gray JA, Compton-Toth BA and Roth BL (2003) Identification of two serine residues essential for agonist-induced 5-HT2A receptor desensitization. Biochemistry 42:10853-10862.

Kim SJ, Veenstra-VanderWeele J, Hanna GL, Gonen D, Leventhal BL and Cook EH, Jr. (2000) Mutation screening of human 5- $\mathrm{HT}_{2 \mathrm{~B}}$ receptor gene in early-onset obsessive-compulsive disorder. Mol. Cell. Probes 14:47-52.

Kitamura K, Singer WD, Star RA, Muallem S and Miller RT (1996) Induction of inducible nitric-oxide synthase by the heterotrimeric G protein Galpha13. J. Biol. Chem. 271:7412-7415.

Launay J-M, Birraux G, Bondoux D, Callebert J, Choi D-S, Loric S and Maroteaux L (1996) Ras involvement in signal transduction by the serotonin 5-HT $2 \mathrm{~B}$ receptor. J. Biol. Chem. 271:3141-3147.

Launay JM, Hervé P, Peoc'h K, Tournois C, Callebert J, Nebigil C, Etienne N, Drouet L, Humbert M, Simonneau G and Maroteaux L (2002) Function of the serotonin 5-hydroxytryptamine $2 \mathrm{~B}$ receptor in pulmonary hypertension. Nat. Med. 8:1129-1135.

Lefkowitz RJ and Whalen EJ (2004) beta-arrestins: traffic cops of cell signaling. Curr. Opin. Cell. Biol. 16:162-168.

Liu B and Wu D (2003) The first inner loop of endothelin receptor type B is necessary for specific coupling to Galpha 13. J. Biol. Chem. 278:2384-2387.

Manivet P, Mouillet-Richard S, Callebert J, Nebigil CG, Maroteaux L, Hosoda S, Kellermann O and Launay J-M (2000) PDZ-dependent activation of nitric-oxide synthases by the serotonin $2 \mathrm{~B}$ receptor. $J$. Biol. Chem. 275:9324-9331.

Miller WE and Lefkowitz RJ (2001) Expanding roles for beta-arrestins as scaffolds and adapters in GPCR signaling and trafficking. Curr. Opin. Cell. Biol. 13:139-145.

Nagao M, Kaziro Y and Itoh H (1999) The Src family tyrosine kinase is involved in Rho-dependent activation of c-Jun N-terminal kinase by Galpha12. Oncogene 18:4425-4434.

Nebigil CG, Etienne N, Messaddeq N and Maroteaux L (2003) Serotonin is a novel survival factor of cardiomyocytes: mitochondria as a target of 5-HT $2 \mathrm{~B}$-receptor signaling. FASEB J. 17:1373-1375. 
Nebigil CG, Launay J-M, Hickel P, Tournois C and Maroteaux L (2000) 5-Hydroxytryptamine 2 receptor regulates cell-cycle progression: Cross talk with tyrosine kinase pathways. Proc. Natl. Acad. Sci. USA 97:2591-2596.

Parker LL, Backstrom JR, Sanders-Bush E and Shieh BH (2003) Agonist-induced phosphorylation of the serotonin 5-HT2C receptor regulates its interaction with multiple PDZ protein 1. J. Biol. Chem. 278:21576-21583.

Porter RH, Malcolm CS, Allen NH, Lamb H, Revell DF and Sheardown MJ (2001) Agonist-induced functional desensitization of recombinant human 5-HT2 receptors expressed in CHO-K1 cells. Biochem. Pharmacol. 62:431-438.

Roth BL and Shapiro DA (2001) Insights into the structure and function of 5-HT(2) family serotonin receptors reveal novel strategies for therapeutic target development. Expert. Opin. Ther. Targets 5:685695.

Sakmar TP, Menon ST, Marin EP and Awad ES (2002) Rhodopsin: insights from recent structural studies. Annu. Rev. Biophys. Biomol. Struct. 31:443-484.

Shepard LW, Yang M, Xie P, Browning DD, Voyno-Yasenetskaya T, Kozasa T and Ye RD (2001) Constitutive activation of NF-kappa B and secretion of interleukin-8 induced by the G protein-coupled receptor of Kaposi's sarcoma-associated herpesvirus involve $\mathrm{G}$ alpha(13) and RhoA. J. Biol. Chem. 276:45979-45987.

Spiegel AM and Weinstein LS (2004) Inherited diseases involving G proteins and G protein-coupled receptors. Annu. Rev. Med. 55:27-39.

Tournois C, Mutel V, Manivet P, Launay JM and Kellermann O (1998) Cross-talk between 5hydroxytryptamine receptors in a serotonergic cell line. Involvement of arachidonic acid metabolism. $J$. Biol. Chem. 273:17498-17503.

Ullmer C, Boddeke HGWM, Schmuck K and Lübbert H (1996) 5- $\mathrm{HT}_{2 \mathrm{~B}}$ receptor-mediated calcium release from ryanodine-sensitive intracellular stores in human pulmonary artery endothelial cells. $B r . J$. Pharmacol. 117:1081-1088. 
Ullmer C, Schmuck K, Figge A and Lubbert H (1998) Cloning and characterization of MUPP1, a novel PDZ domain protein. FEBS Lett. 424:63-68.

Xia Z, Gray JA, Compton-Toth BA and Roth BL (2003) A direct interaction of PSD-95 with 5-HT2A serotonin receptors regulates signal transduction and receptor trafficking. J. Biol. Chem. 278:2190121908. 


\section{Footnotes}

This work has been supported by funds from the Centre National de la Recherche Scientifique, the Institut National de la Santé et de la Recherche Médicale, the Hôpital Universitaire de Strasbourg, the Université Louis Pasteur, and by grants from the Fondation de France, the Fondation pour la Recherche Médicale, the Association pour la Recherche contre le Cancer, the French ministry of research (Actions Concertées Incitatives) and the European Community. 


\section{Legends for Figures}

FIG. 1. Comparison of the effects of selected ligands on the coupling of the 5-HT $2 \mathrm{~B}$ receptor to the WT and the R393X receptor. The dose-response effect of agonists (top four panels) on NOS activity has been directly followed by NOS activity assay (right four panels). In the case of MAPK, direct kinase assay was used to assessed MAPK activity (left four panels). The antagonist effect (four bottom panels) to the receptor was assessed through competition 5-HT effect. Ten different concentrations of each drug were used. Reported values are the means of four independent experiments performed in triplicates and are expressed as percent of 5-HT effects on wiltype receptor. Deduced absolute values \pm SEM for EC50, Emax and $\mathrm{K}_{B}$ and statistical significance are shown on the table.

FIG. 2. $\mathbf{G} \alpha_{13}$ is involved in the $5-\mathbf{H T}_{2 \mathrm{~B}}$ receptor-mediated thymidine incorporation. The thymidine incorporation evaluated $24 \mathrm{~h}$ after stimulation and represented as fold basal incorporation is significantly elevated by $1 \mu \mathrm{M}$ serotonin in wildtype receptor and by $100 \mathrm{nM}$ and $1 \mu \mathrm{M}$ in mutant receptor (A). Basal thymidine incorporation was $5516 \pm 76 \mathrm{dpm} / \mathrm{mg}$ of prot for wildtype and $9345 \pm 105 \mathrm{dpm} / \mathrm{mg}$ of prot for the mutant receptor $(n=8)$. Exposing permeabilized cells to $G_{\alpha q}$ and $G_{\alpha 13}$ antibodies significantly interferes with the wildtype 5- $\mathrm{HT}_{2 \mathrm{~B}}$ receptor-mediated thymidine incorporation but not to antibodies against $\mathrm{G}_{\alpha \mathrm{s}}(B)$. Antibodies against $\mathrm{G}_{\alpha 13}$ nearly completely abolished serotonin-induced thymidine incorporation, but antibodies against $\mathrm{G}_{\alpha \mathrm{\alpha}}$ or $\mathrm{G}_{\alpha \mathrm{\alpha q}}$ had no effect on the $\mathrm{R} 393 \mathrm{X}$ 5-HT $2 \mathrm{~B}$ receptor response. * $\mathrm{P}<0.05$ vs. unstimulated cells, $\dagger \mathrm{P}<0.05$ vs. $1 \mu \mathrm{M}$ serotonin stimulated cells, White bars, WT control; shaded bars, $\mathrm{R} 393 \mathrm{X}$ 5-HT $2 \mathrm{~B}$ receptor.

\section{FIG. 3. Internalization of 5-HT $2 \mathrm{~B}$ receptor wildtype and R393X 5-HT $\mathrm{T}_{2 \mathrm{~B}}$ receptor mutant.}

Series of single confocal plane images were taken from living $\mathrm{LMTK}^{-}$cells expressing $5-\mathrm{HT}_{2 \mathrm{~B}}$ receptorpEYFP wildtype (WT) or R393X 5-HT2B receptor-pEYFP by time lapse video after stimulation. (A). Distribution of 5- $\mathrm{HT}_{2 \mathrm{~B}}$ receptor expressed at 0 and $30 \mathrm{~min}$ of serotonin stimulation. Corresponding sets of images are shown as supplementary videos. These images are representative of 3 cells observed in each of 
at least 4 independent experiments. Bars $2 \mu \mathrm{M}$. (B). Internalization kinetics for wildtype 5-HT $2 \mathrm{~B}$ receptorpEYFP and R393X 5-HT $2 \mathrm{~B}$ receptor-pEYFP after stimulation by $1 \mu \mathrm{M}$ serotonin assessed by fluorescence intensity from more than 5 different regions of interest per cell at the membrane and expressed as percent of unstimulated cells \pm SEM. 
NOS

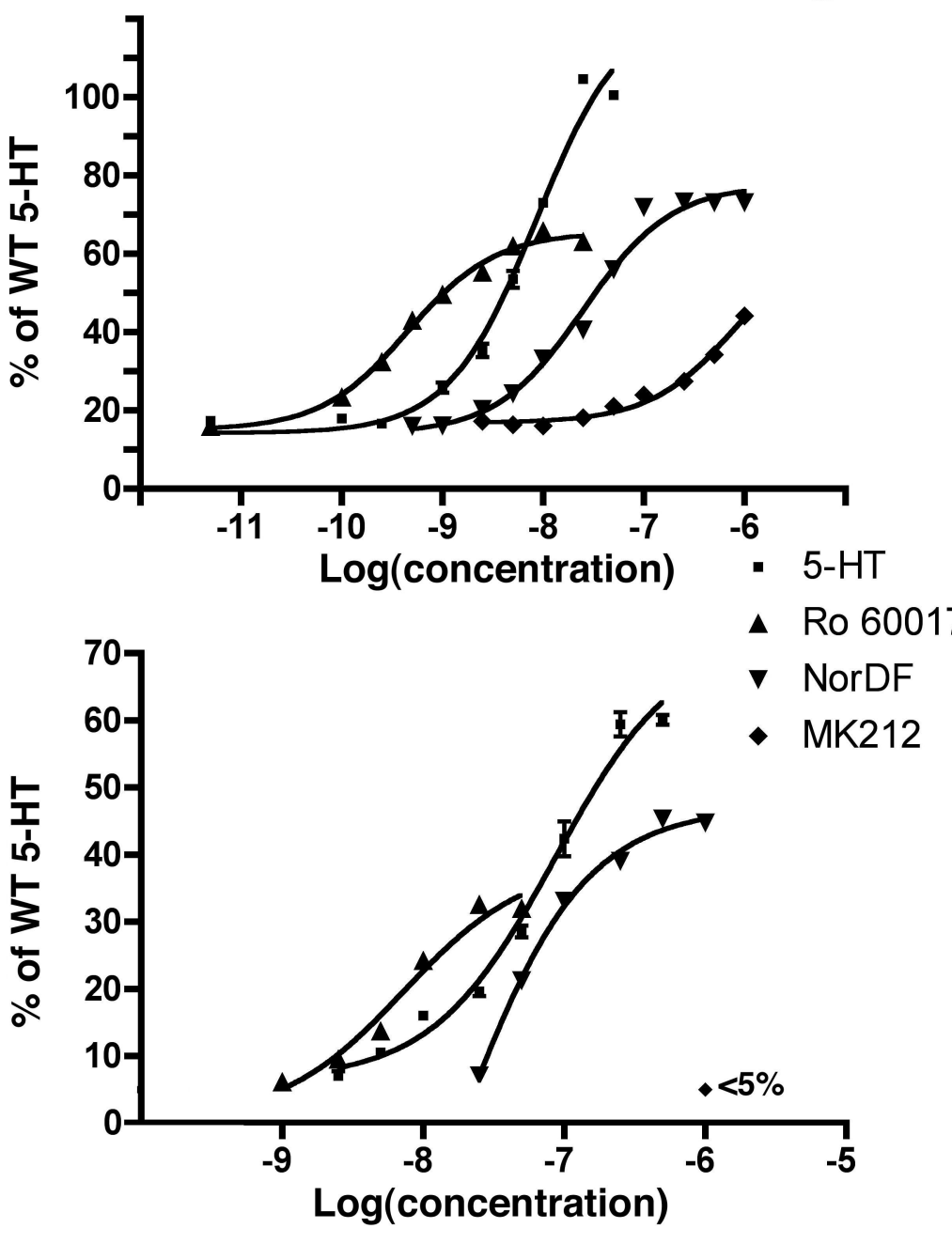

NOS

Antagonists
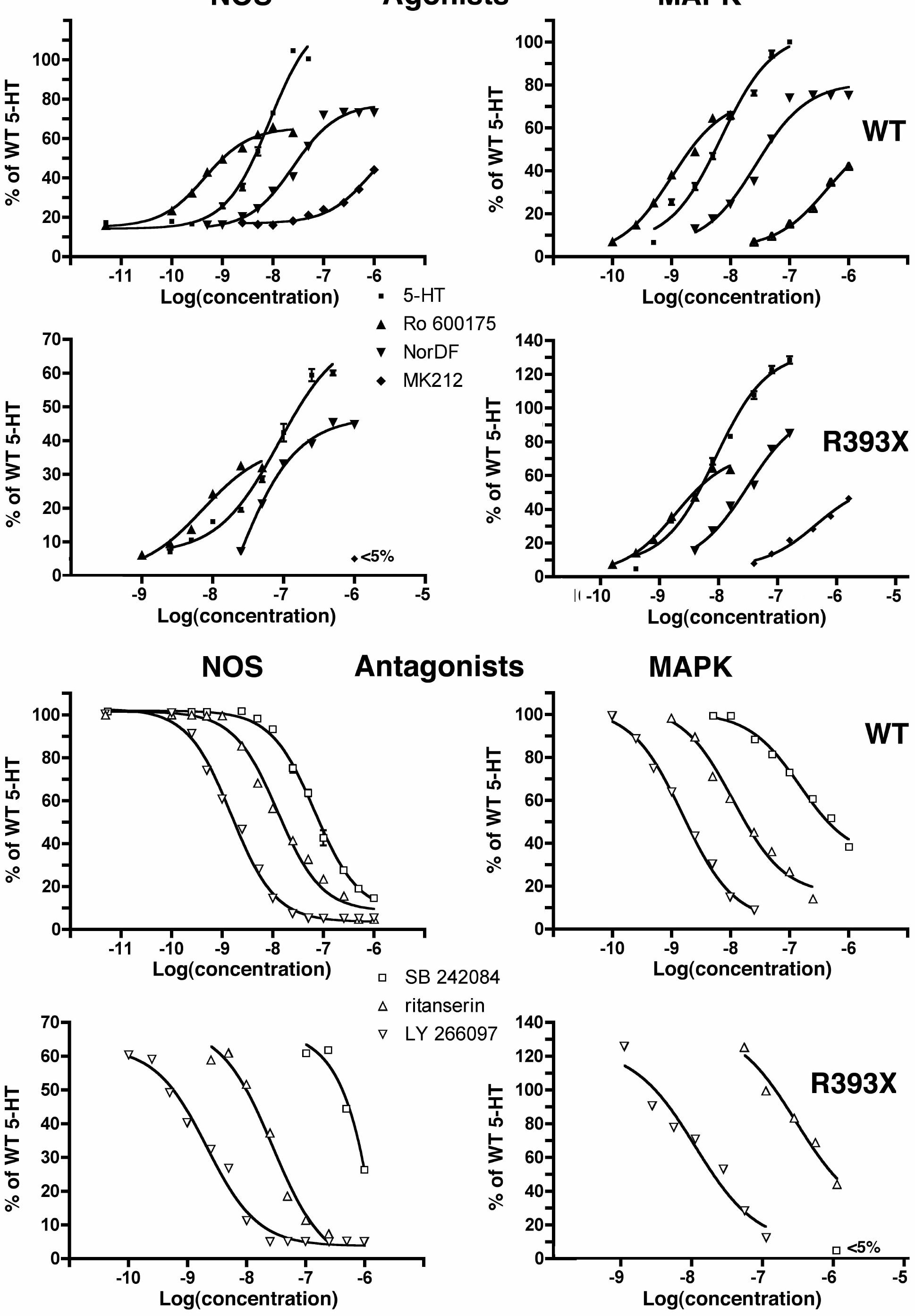
Figure 2
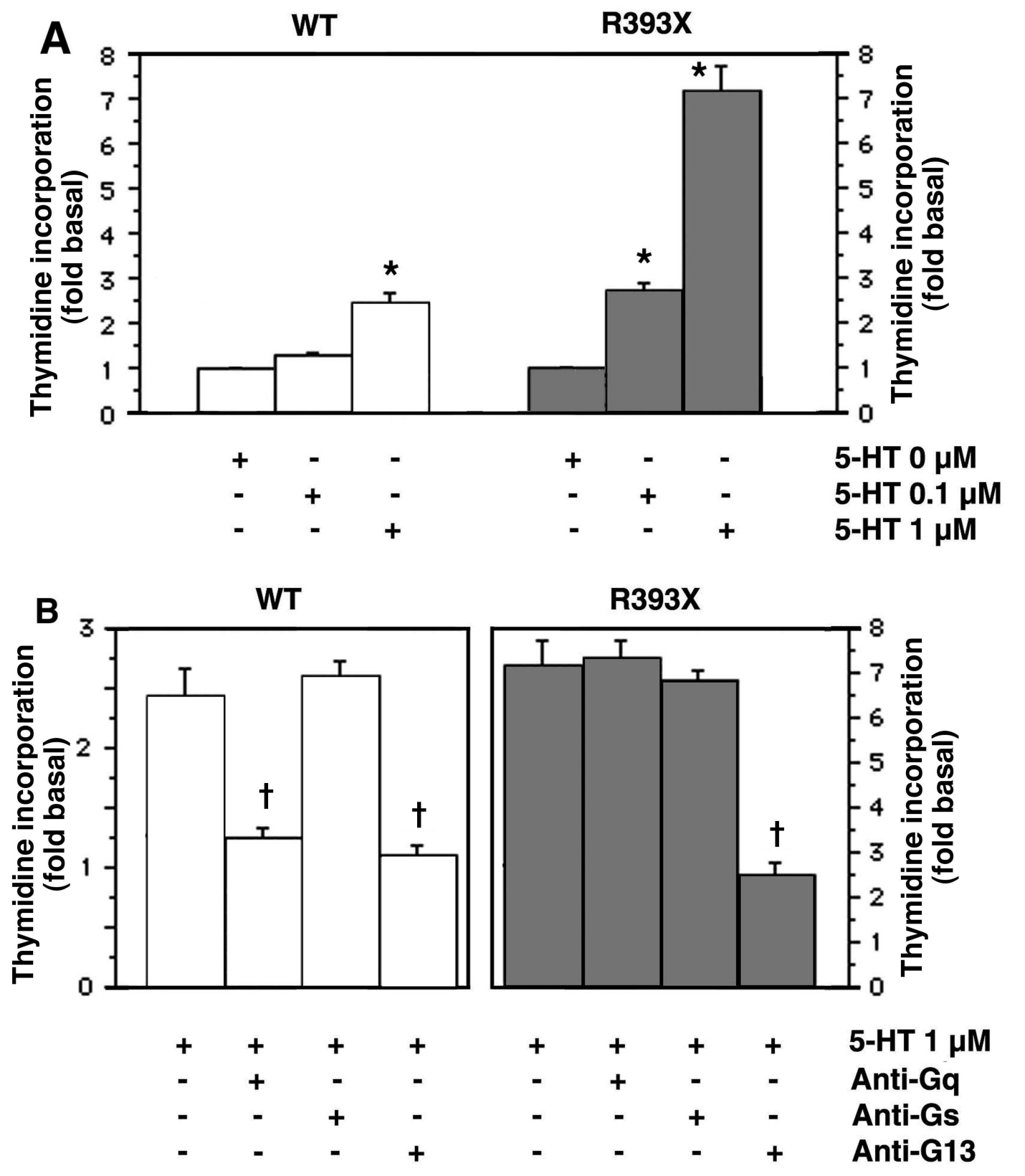
Figure 3

A

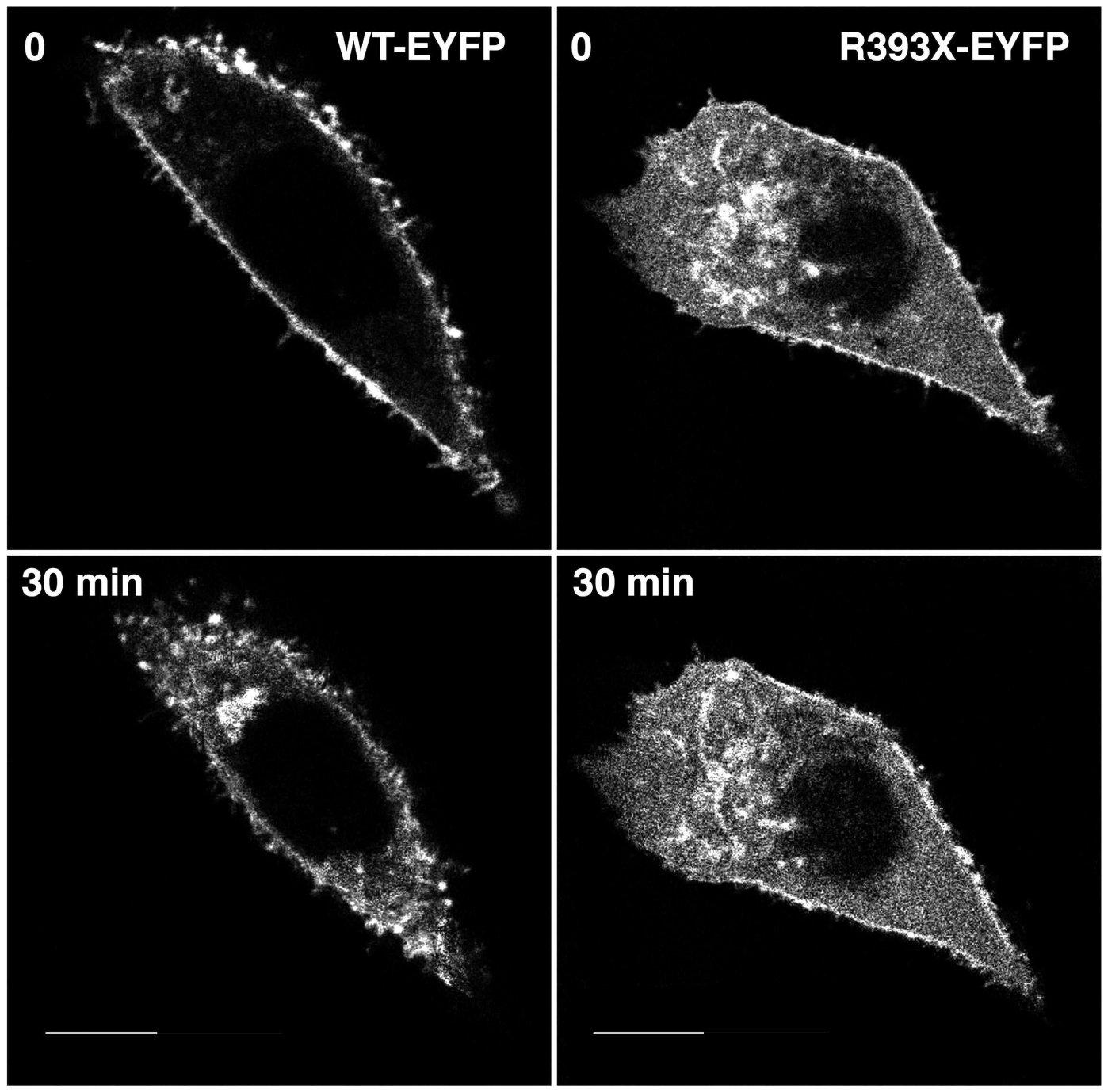

B

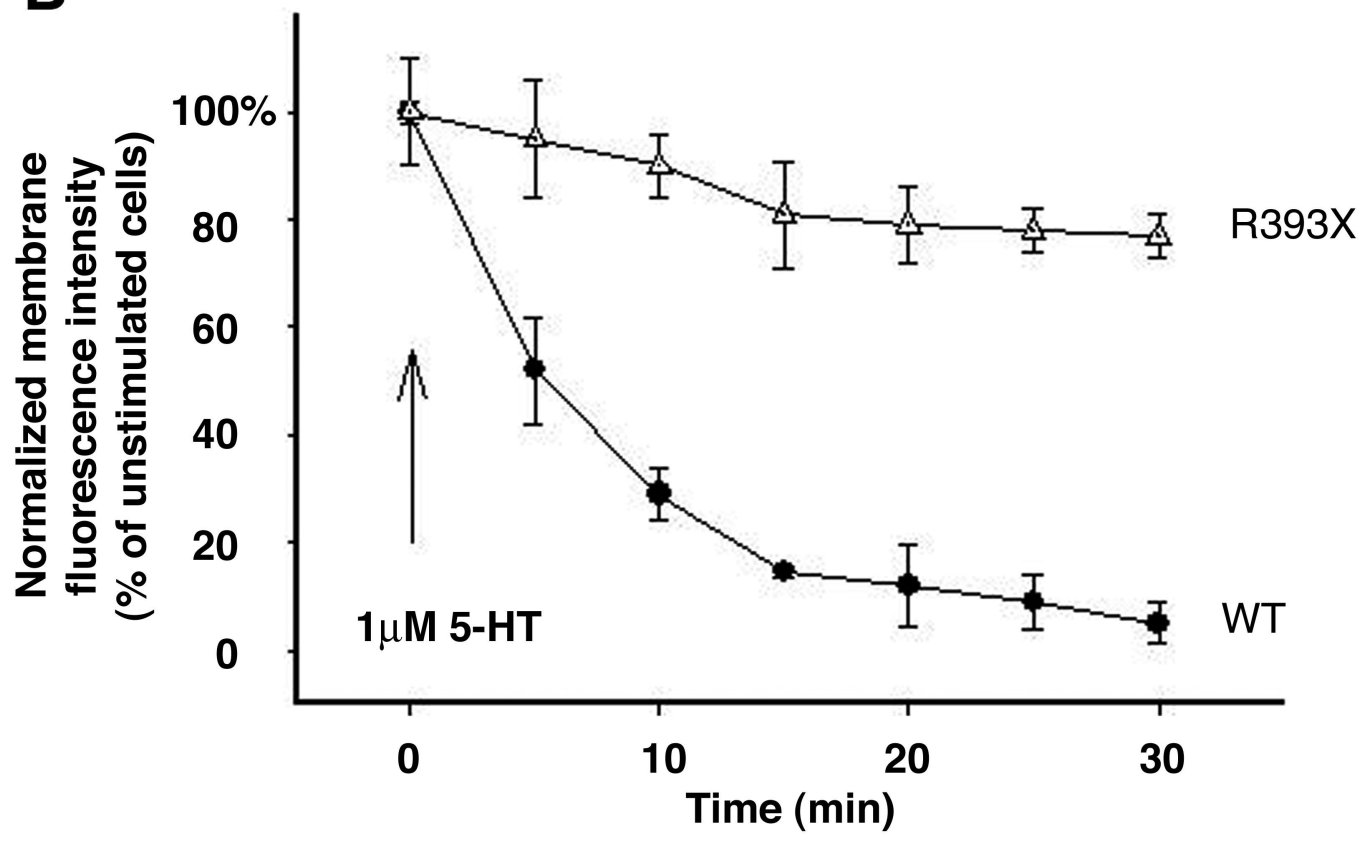




\section{$\mathrm{HT}_{2 \mathrm{~B}}$ WT}

binding

agonist

MK 212

Ro 600332

DOI

BW 723C86

Ro 600175

norDF

$5-\mathrm{HT}$
$\mathrm{IP}_{3}$

$\mathrm{EC} 50(\mathrm{nM}) \quad \operatorname{Emax}(\%)$

$468 \pm 31 \quad 62 \pm 8$

$24 \pm 2 \quad 91 \pm 7$

$7.9 \pm 0.7 \quad 68 \pm 8$

$5.1 \pm 0.8 \quad 92 \pm 9$

$0.69 \pm 0.07 \quad 84 \pm 7$

$18 \pm 2 \quad 91 \pm 1$

$4.6 \pm 0.7 \quad 100 \pm 5$

\begin{tabular}{llll}
\multicolumn{2}{c}{ NOS activity } & \multicolumn{2}{c}{ MAPK activity } \\
EC50 (nM) & Emax (\%) & EC50 (nM) & Emax $(\%)$ \\
$178 \pm 27$ & $42 \pm 5$ & $151 \pm 36$ & $41 \pm 11$ \\
$66 \pm 6$ & $39 \pm 4$ & $76 \pm 6$ & $34 \pm 9$ \\
$16 \pm 3$ & $43 \pm 6$ & $17 \pm 5$ & $43 \pm 8$ \\
$23 \pm 4$ & $56 \pm 7$ & $25 \pm 7$ & $52 \pm 11$ \\
$0.66 \pm 0.06$ & $64 \pm 8$ & $0.71 \pm 0.18$ & $65 \pm 8$ \\
$22 \pm 4$ & $73 \pm 9$ & $22 \pm 4$ & $73 \pm 3$ \\
$5.6 \pm 0.4$ & $100 \pm 6$ & $6.0 \pm 0.8$ & $100 \pm 7$
\end{tabular}

\section{R393X}

binding $\quad \mathrm{IP}_{3}^{* *} \quad$ NOS activity MAPK activity

$\mathrm{Ki}(\mathrm{nM}) \mathrm{EC} 50(\mathrm{nM}) \quad \operatorname{Emax} \quad \mathrm{EC} 50(\mathrm{nM}) \quad \operatorname{Emax}(\%) \quad \operatorname{EC} 50(\mathrm{nM}) \quad \operatorname{Emax}(\%)$

$89 \pm 5 *>1000 \quad$ nd $>1000 \quad$ nd $^{* *} \quad 120 \pm 22 \quad 47 \pm 8$

$107 \pm 5 *>1000$ nd $240 \pm 26 * * \quad 21 \pm 5 * \quad 15 \pm 1 * * \quad 67 \pm 10^{*} *$

$22 \pm 6>1000 \quad$ nd $135 \pm 16^{* *} \quad 14 \pm 4 * \quad 7.6 \pm 0.8^{*} \quad 52 \pm 11$

$14 \pm 3>1000 \quad$ nd $98 \pm 7 * * \quad 23 \pm 7 * \quad 3.5 \pm 0.8 * * \quad 61 \pm 7$

$0.5 \pm 0.2>1000 \quad$ nd $\quad 5.9 \pm 0.8^{* *} \quad 32 \pm 6^{*} \quad 0.63 \pm 0.02 \quad 64 \pm 12$

$17 \pm 1>1000$ nd $87 \pm 6^{* *} \quad 45 \pm 8^{*} \quad 12 \pm 3 * \quad 86 \pm 5^{*}$

$4.9 \pm 0.8>1000 \quad$ nd $56 \pm 7 * * \quad 60 \pm 9^{*} \quad 3.1 \pm 0.5^{*} \quad 127 \pm 4 *$

antagonist (vs. 5-HT)

lisuride

Ro 600869

RS 102221

SB 242084

ketanserine

mesulergine

SB 206553

mianserin

ritanserin

SB 215505

SB 204741

LY 266097

RS 127445

MDL 100907

$\mathrm{KB}(\mathrm{nM})$
$1.2 \pm 0.3$
$63 \pm 6$
$436 \pm 15$
$37 \pm 5$
$209 \pm 29$
$2.8 \pm 0.5$
$5.6 \pm 0.3$
$5.9 \pm 0.8$
$1.4 \pm 0.4$
$9.0 \pm 0.1$
$44 \pm 6$
$0.18 \pm 0.06$
$0.49 \pm 0.10$
$67 \pm 7$

$\mathrm{KB}(\mathrm{nM})$
$1.3 \pm 0.6$
$8.5 \pm 0.8$
$78 \pm 5$
$36 \pm 3$
$151 \pm 12$
$10.5 \pm 0.7$
$7.4 \pm 1.3$
$7.1 \pm 0.9$
$8.7 \pm 1.0$
$2.2 \pm 0.4$
$67 \pm 6$
$0.65 \pm 0.06$
$0.43 \pm 0.07$
$245 \pm 16$

KB $(\mathrm{nM})$
$2.1 \pm 0.9$
$7.1 \pm 0.9$
$89 \pm 9$
$49 \pm 8$
$93 \pm 12$
$4.5 \pm 0.8$
$21 \pm 3$
$33 \pm 5$
$6.9 \pm 0.8$
$1.8 \pm 0.5$
$60 \pm 8$
$0.71 \pm 0.07$
$0.45 \pm 0.08$
$155 \pm 19$

$\begin{array}{ll} & \text { KB }(\mathrm{nM}) \\ 1.3 \pm 0.4 & \text { nd } \\ 11.2 \pm 1.1 & \text { nd } \\ 174 \pm 8^{*} & \text { nd } \\ 53 \pm 4^{*} & \text { nd } \\ 35 \pm 6 & \text { nd } \\ 2.9 \pm 0.4 & \text { nd } \\ 7.9 \pm 0.3 & \text { nd } \\ 7.6 \pm 0.6^{*} & \text { nd } \\ 7.1 \pm 0.9 & \text { nd } \\ 1.4 \pm 0.1 & \text { nd } \\ 71 \pm 4 & \text { nd } \\ 0.33 \pm 0.11 & \text { nd } \\ 0.30 \pm 0.09 & \text { nd } \\ 81 \pm 3 & \text { nd }\end{array}$

$\mathrm{KB}(\mathrm{nM})$
$7.4 \pm 0.3^{*}$
$17.4 \pm .7^{*}$
$302 \pm 26^{* *}$
$123 \pm 16^{* *}$
$115 \pm 19$
$8.5 \pm 0.7$
$29 \pm 5^{* *}$
$25 \pm 2^{* *}$
$12 \pm 1$
$6.0 \pm 0.8^{*}$
$148 \pm 13^{* *}$
$1.07 \pm .15^{*}$
$0.52 \pm 0.09$
$166 \pm 17^{*}$

$\mathrm{KB}(\mathrm{nM})$

$13 \pm 3 *$

$9.3 \pm 0.8$

$>1000^{* * *}$

$158 \pm 20 * *$

$141 \pm 15^{*}$

$15 \pm 1 * *$

$102 \pm 27 * *$

$229 \pm 24 * *$

$138 \pm 18 * *$

$13 \pm 2 * *$

$759 \pm 61 * *$

$2.3 \pm 0.6^{*}$

$0.49 \pm 0.31$

$181 \pm 16$

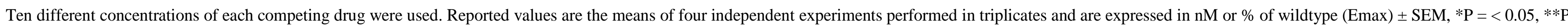

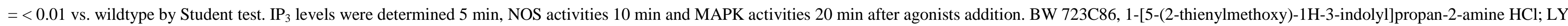

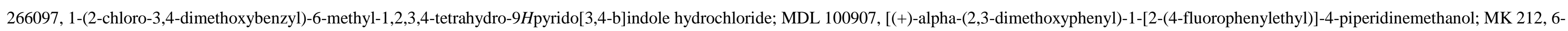

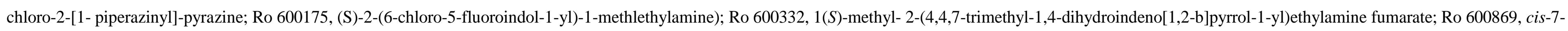

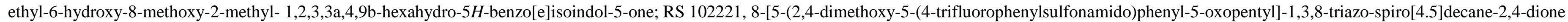

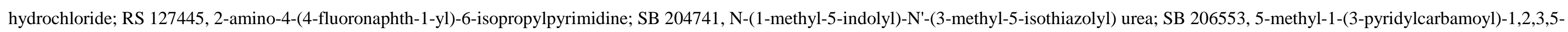

tetrahydropyrrolo[2 ,3-f]indole; SB 215505, 6-chloro-5-methyl-1-(5-quinolylcarbamoyl) indoline; SB 242084, 6-chloro-5-methyl-1-[2-(2-methylpyridyl-3-oxy)-pyrid-5-yl carbonyl] indoline. 